\title{
2 Religion and extractive industries: ethics, practice, and engagement
}

\author{
Katherine Marshall ${ }^{1}$
}

\section{Religious engagement: framing patterns and legitimacy}

Extractive industries present a classic challenge: they can be a mainstay and a powerful engine for good in an economy and society, but they can also be a source of distortions, tension, and conflict, to a point that the term "curse" is often applied to an abundance of such resources. Policies towards extractive industries are thus keenly debated in development strategies. A particular concern is that extractives have significant bearing on many conflicts; they are often linked to political, intra-state, and inter-state conflicts that surround the control and distribution of resources, land, and the revenues these resources produce. In some instances, directly or indirectly, religious tensions and conflicts are also involved.

The complexity of the diverse roles that extractive enterprises play is exemplified by how mining can be plotted to each of the UN Sustainable Development Goals (Columbia Center on Sustainable Development et al. 2016, 5). The many controversies around extractive industries include environmental challenges, physical scars to landscapes, inequitable distribution of benefits, propensities to large-scale corruption, and the impact on people directly and indirectly affected, including abuses of their human rights. As mining ventures extend deep into areas where indigenous communities live, their voices, rights, and ways of life are of central concern. Deep-sea mining also involves issues around disruption of the environment, and law and international justice. Each of these topics affect and involve religious communities.

Extractive industries rarely involve religious institutions directly. However, distinctive aspects of both extractive policy and operations have engaged religious actors in varying advocacy and negotiation efforts. Effects of mining on communities and relationships between communities and mining companies in many regions have spurred religious activism ranging from social and spiritual support to participation in active protests against, notably, large mining operations and government support for them. Ancient traditions of artisanal mining can also give rise to tensions and conflict. The significance for national and community welfare 
of extractive policies and operations has led to active dialogue, analysis, and advocacy related to pertinent policy issues, such as taxation and environmental standards. Individually and collectively, religious actors can be powerful witnesses about the impact of mining, sharing knowledge and experience and highlighting vital ethical aspects. Religious peacebuilding, including direct mediation, is particularly significant in fragile and conflict-prone states, where many of the most controversial extractive investments are concentrated. Their actual and potential roles draw on their presence in mining areas, the trust they enjoy, and their willingness to highlight abuses of human rights and the vulnerability of affected communities.

This chapter explores evolving debates on extractive industry approaches and relevant policies, global and national, from the perspective of a range of religious actors who may speak from a specific tradition or community, or in an interfaith or intra-faith context. It situates various forms of involvement of religious actors, including the Catholic Church and interreligious and intra-faith bodies, within the broader, evolving policy debates about the roles of extractive industries in development strategies. Its focus is primarily on global forums, referring to country experiences to illustrate religious actor engagement. Driving questions include: How are concerns translated into action? Where has the impact of religious advocacy and action been most effective? And what are likely and productive avenues for the future?

Systematic frameworks for religious engagement in these debates are not clearly defined. Indeed, as with many development issues, efforts by religious actors to be part of global and national policy discussions can be met with skepticism as to their legitimacy in these settings. Demonstrating relevance and legitimacy as a stakeholder is thus a common challenge. Recent explicit focus by Catholic Church entities and the Church of England are prominent examples of both interest and capacity to engage. Debates and controversies extend from very local levels to transnational and global ones. Each situation is distinct, and religious engagement at local and national levels shows wide variation. It may address new mining ventures, distribution of resources and revenues, or community impacts such as forced resettlement and contaminated water. Efforts to address extractive industry policies at global and transnational levels also vary, both as to institutional engagement and positions on specific issues. Cases of systematic and effective religious engagement on national policies are quite rare, however, and overall suggests rather fragmented approaches. There is ample room for more cooperation and informed engagement in policy debates.

\section{Evolving policy landscapes}

Debates about extractive industries and their roles in development have evolved significantly in recent decades. Various broad trends in global 
agendas have tended to sharpen the focus on both opportunities and conflicts where mining ventures are concerned. The debates have been shaped by broader shifts in approaches both to development strategies and to the roles that extractive industries play in country and transnational strategies. Conflicts, especially with multinational mining companies, have contributed to shifts in approach and prompted engagement and reflection. These shifts have in turn affected the evolving engagements which have taken many forms between religious and development actors. These topics are summarized briefly here.

\section{Corporate social responsibility and business practices}

The spotlight for international development has turned increasingly to the ethics and practices of private business, reflecting in part the rapidly expanding roles of private finance for poor country development. Elaboration of approaches to Corporate Social Responsibility (CSR) has been one response, ranging from local charitable works to a full alignment of a business to social goals. Raymond Offenheiser's chapter takes up the latter in its argument that church actors should focus on advocacy to make mining companies into genuine development partners that engage in a robust and substantive way with communities' development goals. Business and Human Rights (BHR) represents a parallel development, of which Douglass Cassel's chapter is a good example. BHR reflects both internal and external pressures on companies to respond to concerns exemplified by extractive industry debates and tensions. A continuing issue is the voluntary nature of CSR and BHR (see Ramasastry 2015; Carter 2017; Gamu and Dauvergne 2018). A significant framework is the UN Global Compact, which was launched in 1999 and defines principles addressing corporate responsibility in a broader context. Companies are to measure conduct against international law, though without binding or enforceable rules. In practice, while the frameworks are far better articulated than in the past, with admirable principles as the foundation, governance, and enforcement of laws remain the responsibility of the relevant state.

\section{Corruption and governance}

The large resources involved in mining enterprises and often obscure financial flows have linked extractive industries to broader issues around transparency, corrupt practices, and capital flight. Concerns include the realities of substantial corruption associated with mining ventures and awareness that imbalances of power and various interests at work mean that host governments and especially communities get a raw deal, benefitting little from lucrative agreements. Global integrity movements aimed at bringing facts to light include the Extractive Industries Transparency 


\section{Katherine Marshall}

Initiative (EITI) (see Milin 2016), ${ }^{2}$ Publish What you Pay (see van Oranje and Parham 2009), ${ }^{3}$ as well as broader initiatives by global integrity alliances, notably Transparency International. ${ }^{4}$

EITI is of particular note, reflecting transnational efforts to make information more transparent, and set and enforce standards for good governance of oil, gas, and mineral resources. Established in 2002, it requires disclosure of information along the extractive industry value chain: how licenses and contracts are allocated and registered; who the beneficial owners of those operations are; the fiscal and legal arrangements; how much is produced; how much is paid; where the revenue is allocated; and contributions to the economy, including employment. EITI now includes fifty-five countries, each expected to publish an annual report disclosing information on contracts and licenses, production, revenue collection, revenue allocation, and social and economic spending. A quality-assurance mechanism is scheduled for at least every three years to assess performance towards meeting the EITI Standard and promote dialogue and learning at the country level. Efforts to hold all EITIimplementing countries to the same global standard is the key mechanism, and each implementing country has a national secretariat and multi-stakeholder group made up of representatives from the country's government, extractive companies, and civil society. An international multi-stakeholder board oversees the standard from a base in Oslo, Norway. The weakest element is that EITI depends on voluntary disclosure. Challenges include establishing consistency across national and international standards and meeting compliance costs.

Among issues that the EITI community has taken up is gender. This involves explicit assessment of the impact on women and girls of mining ventures and, more broadly, the benefits of diversity (or negative impact of a lack thereof). Women and girls bear a disproportionate share of the negative social, economic, and environmental impacts of extractives, and the goal of enhancing women's participation in decision-making around the management, development, and use of natural resources is now included in the recently revised EITI Standard (Thévoz 2019).

\section{Principles of engagement with local communities and civil society organizations, including safeguarding policies applicable to multilateral financing organizations}

A marked shift in development approaches concerns the roles of nongovernment actors (civil society) and approaches to engagement with communities. From an early tendency to rely on expertise, often external, with no formal mechanisms for engaging communities, practice shifted first to consultation, then to participation, and, today, to what is often termed empowerment, reflecting a conviction that local communities have both rights 
and wisdom in determining actions for their development. Such practices are expected and often required, for example in development strategies elaborated by development partners and in the poverty-reduction strategies that form part of debt-relief packages. The multilateral investment banks have been a focus of much discussion because, although their financing roles often represent a limited share of overall investments, their policies have tended to shape much of the dialogue around extractive policy approaches. For instance, the chapter by Holden and Montevecchio explains how World Bank mining policy in Africa influenced the Philippine Mining Act of 1995.

These processes have taken on special significance for communities that may not be fully integrated in national political systems, especially indigenous communities, where many tensions around extractive industries arise. This lies behind the effort to elaborate definitions and processes of "meaningful participation," notably through the development of standards and practices for free, prior, and informed consent (FPIC) (see Goodland 2004; Callies, Curtin, and Tappendorf 2003). These principles are enshrined in various international and national covenants, although there are continuing debates as to what each word represents and whether efforts to assure FPIC are indeed applied in practice.

\section{Indigenous peoples}

The rights of indigenous communities have particular significance for extractive industries debates, both because of egregious cases of abuse and because mining sites are increasingly being developed in areas occupied by indigenous communities. Thus, various efforts have been made to protect and assure the rights of these communities, shown in the chapters from Karl Gaspar on the Philippines and José Bayardo Chata Pacoricona on Peru. One milestone is the 2007 United Nations Declaration on the Rights of Indigenous People, which supports the principle that states should seek FPIC from indigenous groups regarding any measures affecting them.

\section{Environmental protection}

Concerns about environmental damage and the impact of fossil fuels on climate change have mounted over the decades and can now be seen as a central strategic concern for development strategies and approaches. This concern has highlighted links between mining practices and environmental protection. The environmental focus has sharpened over the years, with attention to safeguarding policies that assure full assessment and review of environmental impact of mining ventures, as well as protection of rainforests and biodiversity. These concerns link also to the land rights of affected populations as well as, for example, the negative effects of mining ventures on water supplies. 


\section{Katherine Marshall}

\section{Fragility, conflict prevention, and peacebuilding}

Many tensions and concerns about extractive industry practices and investments are centered in countries that are considered fragile, including those with violent conflicts. This reflects the association of poor governance and fragility, situations where abuses of power and neglect of sound policies and practices are accentuated. The concerns are heightened by the fact that tensions around natural resources can be a cause or accelerator of conflicts and can affect cost structures and risk assessments. Such tensions and competition involving extractive resources have often proved destabilizing. Over the past sixty years, an estimated forty percent of civil wars can be associated with natural resources; since 1990, at least eighteen violent conflicts have been fueled by the exploitation of natural resources. Rebel groups can exploit natural resources to fund war and competition can sharpen polarization. War displaces populations and refugee movements can degrade resource bases. Institutions designed to manage the environment are likely to be disrupted or shut down during a war or violent conflict (UN Interagency Framework Team 2012). This points to the importance of explicit attention to policies and practices towards extractive industries in the broader context of policies on fragility and its links to peacebuilding.

\section{Religious engagement}

Engagement on extractives between development institutions and religious actors, whether religious institutions, non-governmental organizations, or local communities, has been at best unsystematic and partial. In recent years this picture has changed, with a range of institutions and networks whose purpose is to build bridges. However, in many instances, religious actors do not have the assurance of a "seat at the policy table," whether in discussing a national law on mining or on decisions on financing or negotiation of contracts and agreements (Marshall 2021).

There is thus no accepted "place" for religious engagement in many of the international debates that affect extractive industry policies or in efforts to address problems that arise. The role that the Catholic Church plays, at both local and global levels, has grown because of local church experiences with mining in different countries, the active diplomacy of Vatican leaders, and recognition by transnational mining companies, the Majors in particular, of the moral issues involved and the trust that many communities have in the church and its leaders. Likewise, the extensive experience in the sector by the current Archbishop of Canterbury has contributed to his influence and credibility. Religious insight, experience, and engagement are pertinent for each of the topics highlighted above. A question and challenge for the future is how a more systematic and interreligious involvement might emerge and how it might be facilitated and encouraged. Pressures to go beyond rhetoric to operational programs and engagement in national 
development strategies have increased, and tensions reflected in polarization of politics and shrinking civil society space suggest that a wellconceived, collaborative, multireligious engagement might address some of the complex ethical, human rights, and practical challenges involved.

\section{Extractive industry strategies and approaches}

In recent years, various stocktaking efforts, official and academic, have sought to address the increasingly sharp debates about policies and practices for extractive industries with an eye toward their impact on sustainability and development. These continue, with, in a contemporary setting, a particular focus on climate change implications in the leadup to the November 2021 Glasgow COP 26 Summit. But an important early example of both review and tensions was the Extractive Industries Review (EIR) initiated by the World Bank in 2001-2003. It has been followed by numerous other stocktaking reviews, at transnational and national levels, but the essential tensions and difficult debates are illustrative of the polarization on the topic.

The EIR was established primarily in response to pressure from environmental non-governmental ogranizations (NGOs), particularly Friends of the Earth, on the World Bank to stop funding extractive projects. Its framing was shaped by the earlier World Commission on Dams (WCD), which focused on large dam projects which had attracted active protests. But unlike the WCD, the EIR focused on the World Bank Group's (WBG) engagement with the extractive sector. It was led by Emil Salim, ex-Indonesian Minister for the Environment and Population during the 1980s and early 1990s. Salim commissioned a series of fully independent indigenous case studies of the impact of World Bank extractive sector activities on indigenous peoples in Colombia, Cameroon, Papua New Guinea, India, Indonesia, the Philippines, and Russia. The report's review and finalization encountered a rocky path. A draft of the report, released in 2003, omitted inputs from indigenous and non-governmental organizations; however, it concluded that World Bank engagement with the sector was beneficial and should continue. Civil society and indigenous organizations threatened to pull out of the process altogether unless the process changed, ensuring that the final report would be inclusive, independent, and guided by a multi-stakeholder advisory panel that would include at least one indigenous expert. The final report included recommendations for reforms in World Bank policies on human rights and enforceable FPIC standards. The World Bank, however, did not accept many of the EIR's recommendations, notably on indigenous peoples and FPIC, advising that the Bank would only support extractive projects with free, prior, and informed consultation (not "consent") that resulted in the broad community support of affected communities.

Similar debates continue to this day around how well the World Bank and other multilateral banks have or have not implemented effective and 
informed participation of key stakeholders in projects and standards, including approaches to assuring protection of the rights of indigenous peoples (see World Bank 2021; Environmental Defense Fund 2004). Concerns expressed by indigenous peoples and civil society about problems with review processes and consultation procedures persist. Weak follow-up and commitment to act on the findings of sector reviews generate frustration and disillusionment among indigenous organizations and leaders who engaged with these processes. There is a clear need for global mining companies, economists, and development strategists to be more deliberately engaged with communities. Religious actors' witness on the impact of mining can thus have great value. Throughout these different phases and in different ways, religious actors have played growing roles and, in some places and from some perspectives, have had growing force.

\section{Religious and interreligious approaches}

The most prominent instances of religious engagement on extractive industry issues involve the Catholic Church. Since the Catholic Church is the primary focus of this volume, the following sections highlight initiatives of other religious communities and interreligious action, noting areas where religious involvement is weak or absent.

With the notable exception of the Interfaith Center for Corporate Responsibility (ICCR) and linked, more global efforts centered on the management of financial portfolios and engagement of shareholder power to influence policy and behavior, the wide variety of specific and primary actions by different religious groups are focused on specific projects and places. These include, for example, advocacy and protests by the International Network of Engaged Buddhists focused especially on mining activities in Myanmar and in the Philippines, courageous support by Arya Samaj leader Swami Agnivesh for Advasi communities protesting mining ventures in their areas of India, and interfaith efforts to address mining policies in Zimbabwe and Malawi.

The Church of England and the Anglican Communion more broadly have been especially active in policy and advocacy on extractive industries. The national investment bodies of the Church of England-the Church Commissioners, the CBF, and the Pensions Board-recently published the Extractive Industries Policy, in which they threatened to divest from extractive companies that fail to comply with its latest policy on ethical investment (Church of England 2017). The policy was the culmination of two years of theological reflection and research on the industry. Companies have a responsibility to uphold basic standards of human rights; avoid corruption and pay taxes; protect the environment and ecology; and monitor social and economic concerns, such as labor standards, community engagement, fair pay, and collective representation. The policy also bars investments in companies that extract on world heritage or protected sites, 
and warns against the dilution of human rights and health-and-safety standards where joint ventures are undertaken (Williams 2017).

A variety of ecumenical initiatives have focused on extractive industries. These include, within the broader context of its faith and justice work, a diverse set of events and studies by the World Council of Churches (WCC) and its affiliates. For example, there was a session focused on mining at the 2015 World Social Forum (WCC 2015). The president of the All Africa Conference of Churches opened an event with Alternative Mining Indaba in 2011 by highlighting the negative impact of mining both for the environment and for human dignity: "The extractive industries sector has acquired notoriety for being non-transparent and unaccountable. Most problems in the extractive industries are often in developing countries where minerals and oil are being extracted in communities and the proceeds do not benefit these communities" (Mokiwa 2011). And at a 2011 WCC gathering, moving statements were made on the evils of mining, especially in Tanzania:

Open pit mining in Tanzania is destroying God's creation. Arsenic and heavy metals are contaminating water and soil. Health of people near mining areas is deteriorating. Skin diseases are increasing. Farmland is contaminated. Evictions from land have led to loss of human dignity. 400,000 small scale miners have been put out of work and many people have been displaced from their ancestral lands to make way for gold mines. Tanzania as a whole is not benefiting from gold mining. (Hughson 2011)

In Latin America, Iglesias y Minería, an ecumenical coalition of about seventy Latin American Christian organizations, was, from 2013, "united by the challenge of the impacts and violations of socio-environmental rights perpetrated by mining companies in the lands where we live and work." Believing in "the strength of popular organization in our lands, based on the intense work of our Christian leadership and on the spirituality and commitment of our faith communities" the group came together to organize due to "the growing criminalization and persecution of our leadership," whether on the part of the mining companies or national governments. A first meeting in Lima, Peru confirmed the importance of organization of the churches at the grassroots level, of exchange between Christian communities, and of the debate about these issues at stake (Iglesias y Minería, n.d.).

Approaches to the ethical and religious approaches to mining ventures in Islamic institutions and traditions merit a separate study, given extensive global and local experience and wide diversity among country situations. This experience is embedded in relationships between different states and religious bodies and evolving approaches towards, especially, care for the environment (see Zakaria 2020; Gade 2015, 2019). Of particular note is 


\section{Katherine Marshall}

the rich experience in Indonesia, where a succession of fatwas on environmental matters, including mining, have grounded advocacy on religious law (Mangunjaya and Praharawati 2019).

A prominent interfaith effort, with a fifty-year history of activism, is the US-based Interfaith Center on Corporate Responsibility (ICCR). Initially established mostly by Protestant Christian leaders responding to apartheid in South Africa, it has more recently pioneered the use of shareholder advocacy to press companies on environmental, social, and governance issues. Catholic and Jewish groups have joined and the coalition today includes over 300 global institutional investors from different religious traditions, holding more than $\$ 4$ trillion in managed assets. ICCR members include faith-based organizations, socially responsible asset management companies, unions, and foundations.

ICCR members engage company managements to identify and mitigate social and environmental risks resulting from corporate operations and policies. The fundamental proposition is that "responsible and sustainable business practices-and a strong corporate culture of ethics-are in the long-term interest of both companies and investors" (ICCR, n.d.). ICCR members conduct roughly 300 dialogues annually, with over 200 companies, working toward specific goals. ICCR also hosts industry roundtables that convene multiple companies and investors, and other relevant stakeholders like NGOs, community groups, and industry trade associations, to accelerate progress on specific issues.

ICCR has a mining caucus that focuses explicitly on extractive industry issues. The group focuses broadly on how the private sector, and, in some cases, in tandem or conversation with the public sector/government, can play a role in affecting the extractive industries and the forms of development that are taking place. A focus is the need (and the perceived current trend) to move towards more sustainable and ethical forms of development. By incorporating more voices, particularly those of indigenous people, the goal is to remain accountable and responsible to the impacts of the industry, past and present.

Since 2001, initially under the impulse of the UK-based Alliance of Religions for Conservation (ARC), models with some kinship to ICCR have focused on mobilizing the financial resources and shareholder power of faith institutions. The International Interfaith Investment Group (3IG) was established in 2005. While it accomplished some important foundational work, the institution failed. FaithInvest, launched in 2019, seeks, like its predecessors, to establish faith-consistent investment principles so that their investments support environmental and sustainable development, including in the mining sector. ${ }^{5}$

Religions for Peace, the global interreligious body, has engaged on extractive industries through local interreligious councils but has yet to adopt a global approach or focus. During the leadup to the August 2019 Global Assembly in Lindau, Germany, regional consultations were held on major 
focal areas that included Just and Sustainable Societies (Dennis 2020). However, neither in the regional nor the global consultations did extractive industry issues emerge as a central concern.

Aspects of extractive industry policies are relevant for the annual agendas of the G20, and thus the G20 Interfaith Forum has highlighted the work and roles of religious actors in shaping priority policy concerns, notably appropriate engagement with indigenous communities. A session at the 2019 G20 Interfaith Forum highlighted parameters of the debate, including the work of faith communities and leaders with local organizations and peoples to support resistance movements and challenge the mining industry in protecting the rights and livelihoods of the people most affected; philosophical/theological perspectives contesting greed and excessive reliance on technology; and an international investment and development perspective seeking to influence large companies and actors to shift approaches through increased corporate responsibility (Finn 2019). Addressing corruption in the industry has emerged as an area of focus (G20 Interfaith Forum 2020). Extractive industries were alluded to during the 2020 G20 Interfaith Forum and will be on the agenda for the 2021 Forum.

\section{Concluding reflections}

Natural resources have the potential to drive growth, development, and poverty reduction. The extractive industries sector plays a significant economic role in some sixty-three countries (International Monetary Fund 2012). However, many of these countries face challenges, such as resource dependency and weak governance, and many are fragile states. Various multilateral organizations work to support these countries in managing oil, gas, and mining in ways that contribute to sustainable growth and development, protect communities, and reduce carbon emissions. Major areas of focus are strengthening the transparency, governance, institutional capacity, and regulatory processes of countries' extractive sectors. These efforts have particular importance during the COVID-19 emergency, given the need for countries that rely on oil, gas, and mining to boost economic recovery and resilience and protect the poorest and most vulnerable, including those working in artisanal and small-scale mining.

The challenges involved loom large. Apart from longstanding and contemporary contestation around the optimal balance in extractive industry policies and specific challenges around human rights, many states and regions with underexploited mineral resources face intensifying conflicts accentuated by competitive pressures involving industry and local authorities. Conflict has expanded an illegal and unregulated extractive economy.

Common cause and action among religious communities on social justice issues, including extractive industries, is an ideal. This should form an integral part of peacebuilding strategies and action. However, practical efforts to translate such aspirations into practice are partial and, in many 
situations, limited, in part because of the diversity of local situations and different approaches to the complex issues involved. As is the case for the Catholic Church, most mobilization and advocacy is focused on specific cases in specific localities. Given the profound ethical issues involved and the strategic challenges that extractive industries present, building on the examples of constructive religious engagement and cooperation among different parts of religious communities and different traditions offers significant potential to contribute to more sustainable and equitable development strategies at national and regional levels.

\section{Notes}

1 I offer appreciation to Fr. Séamus Finn who provided valuable comments, and Gabrielle Mendelsohn for significant research support.

2 See https://eiti.org/.

3 See https://www.pwyp.org/.

4 See https://www.transparency.org/en.

5 See https://www.faithinvest.org/.

\section{References}

Callies, David L., Daniel R. Curtin, and Julie A. Tappendorf. 2003. Bargaining for Development: A Handbook on Development Agreements, Annexation Agreements, Land Development Conditions, Vested Rights and the Provision of Public Facilities. Washington, DC: Environmental Law Institute.

Carter, Russell A. 2017. "CSR Earns a Seat at the Boardroom Table." Engineering and Mining Journal 218, no. 12: 38-41, 72. https://www.e-mj.com/digital-editions.

Church of England. 2017. "Extractive Industries: The Policy of the National Investing Bodies of the Church of England and the Ethical Investment Advisory Group's Advisory and Theological Papers." https://www.churchofengland.org/sites/default/ files/2018-03/Extractive\%20Industries\%20Policy\%20and\%20Advice.pdf.

Columbia Center on Sustainable Development, UN Sustainable Development Solutions Network, United Nations Development Programme, and World Economic Forum. 2016. "Mapping Mining to the Sustainable Development Goals: An Atlas.” White Paper. World Economic Forum. https://resources.unsdsn.org/ mapping-mining-to-the-sustainable-development-goals-an-atlas.

Dennis, Chelsea. 2020. "Organizing Religious Communities to Work for a Just Peace." Nonprofit Quarterly, March 9, 2020. https://nonprofitquarterly.org/ organizing-religious-communities-to-work-for-a-just-peace.

Environmental Defense Fund. 2004. "Environmental Defense Calls World Bank Response to Extractive Industries Review All Talk and Little Action." August 3, 2004. https://www.edf.org/news/environmental-defense-calls-world-bank-responseextractive-industries-review-all-talk-and-littl.

Finn, Séamus. 2019. "Extractive Industries: The G20 Interfaith Forum Outlines Fundamental Debates and Dilemmas." Berkley Forum, Berkley Center for Religion, Peace and World Affairs, Georgetown University. June 30, 2019. https://berkleycenter.georgetown.edu/responses/extractive-industries-the-g20interfaith-forum-outlines-fundamental-debates-and-dilemmas. 
G20 Interfaith Forum. 2020. “Governance and Accountability: Fighting Corruption in the COVID-19 Emergencies." Policy Brief. October 13, 2020. https://www. g20interfaith.org/app/uploads/2020/09/2020_g20i_policy_brief_governance_and_ corruption.pdf.

Gade, Anna M. 2015. "Islamic Law and the Environment in Indonesia: Fatwa and Dawa." Worldviews: Global Religions, Culture, and Ecology 19, no. 2: 161-183. 10.1163/15685357-01902006.

Gade, Anna M. 2019. Muslim Environmentalisms: Religious and Social Foundations. New York: Columbia University Press. 10.7312/gade19104.

Gamu, Jonathan Kishen, and Peter Dauvergne. 2018. "The Slow Violence of Corporate Social Responsibility: The Case of Mining in Peru." Third World Quarterly 39, no. 5: 959-975. 10.1080/01436597.2018.1432349.

Goodland, Robert. 2004. "Free, Prior and Informed Consent and the World Bank Group." Sustainable Development Law and Policy 4, no. 2: 66-74. https://digitalcommons.wcl.american.edu/sdlp/vol4/iss2/13.

Hughson, Greg. 2011. "Report on the World Council of Churches International Ecumenical Peace Convocation.” https://www.otago.ac.nz/chaplain/otago021114. pdf.

Iglesias y Minería. n.d. "Quiénes Somos.” Accessed May 24, 2021. https:// iglesiasymineria.org/quienes-somos.

Interfaith Center on Corporate Responsibility. n.d. "About.” Accessed May 24, 2021. https://www.iccr.org/about-iccr.

International Monetary Fund. 2012. "Macroeconomic Policy Frameworks for Reseource-Rich Developing Countries.” August 24, 2012. https://www.imf.org/ external/np/pp/eng/2012/082412.pdf.

Mangunjaya, Fachruddin Majeri, and Gugah Praharawati. 2019. "Fatwas on Boosting Environmental Conservation in Indonesia.” Religions 10, no. 10: 570. 10.3390/ rel10100570.

Marshall, Katherine. 2021. "Religion and International Development." In Handbook on Religion and International Affairs, edited by Jeffrey Haynes. London: Routledge (forthcoming).

Milin, Zorka. 2016. "Mapping Recent Developments in Transparency of Extractive Industries." Business and Human Rights Journal 1, no. 2: 321-326. 10.1017/ bhj.2016.8.

Mokiwa, Valentine. 2011. Address at the Meeting of Alternative Mining Indaba, Cape Town. Quoted in Norwegian Church Aid Alliance, "African church leader challenges internatonal mining companies," February 3, 2011. Mines and Communities. http://www.minesandcommunities.org/article.php?a=10724

Ramasastry, Anita. 2015. "Corporate Social Responsibility Versus Business and Human Rights: Bridging the Gap Between Responsibility and Accountability." Journal of Human Rights 14, no. 2: 237-259. https://ssrn.com/abstract=2705675.

Thévoz, Indra. 2019. "Building a Movement for Gender Equality in Extractives." EITI.org. August 28, 2019. https://eiti.org/blog/building-movement-for-genderequality-in-extractives.

UN General Assembly. 2007. UN Declaration on the Rights of Indigenous Peoples. A/RES/61/295. September 13, 2007. https://undocs.org/A/RES/61/295.

UN Global Compact. n.d. "Ten Principles of the UN Global Compact." Accessed May 24, 2021. https://www.unglobalcompact.org/what-is-gc/mission/principles. 


\section{Katherine Marshall}

UN Interagency Framework Team for Preventive Action. 2012. Toolkit and Guidance for Preventing and Managing Land and Natural Resources Conflict. Extractive Industries and Conflict. https://www.un.org/en/land-natural-resourcesconflict/pdfs/GN_Extractive.pdf.

van Oranje, Mabel, and Henry Parham. 2009. Publishing What We Learned: An Assessment of the Publish What You Pay Coalition. London: Publish What You Pay. https://eiti.org/files/documents/Publishing\%20What\%20We\%20Learned.pdf. Williams, Hattie. 2017. "Church of England Targets Extractive Industries." Church Times, November 10, 2017. https://www.churchtimes.co.uk/articles/2017/10november/news/uk/new-church-of-england-policy-targets-extractive-industries.

World Bank. 2021. "Extractive Industries: Overview.” Updated April 26, 2021. https://www.worldbank.org/en/topic/extractiveindustries/overview.

World Council of Churches. 2015. "Churches Speak Against Negative Impact of Mining at World Social Forum.” March 31, 2015. https:/www.oikoumene.org/ news/churches-speak-against-negative-impact-of-mining-at-world-social-forum.

Zakaria, Faizah. 2020. "From Fatwas to Ecumenism: Environmentalism in Southeast Asia.” Berkley Forum, Berkley Center for Religion, Peace and World Affairs, Georgetown University. November 10, 2020. https://berkleycenter.georgetown.edu/ responses/from-fatwas-to-ecumenism-environmentalism-in-southeast-asia. 